\title{
Review Article \\ PPAR Gamma in Neuroblastoma: The Translational Perspectives of Hypoglycemic Drugs
}

\author{
Serena Vella, ${ }^{1}$ Pier Giulio Conaldi, ${ }^{1,2}$ Tullio Florio, ${ }^{3}$ and Aldo Pagano ${ }^{4,5}$ \\ ${ }^{1}$ Department of Laboratory Medicine and Advanced Biotechnologies, IRCCS-ISMETT (Istituto Mediterraneo per i Trapianti e \\ Terapie ad Alta Specializzazione), Palermo, Italy \\ ${ }^{2}$ Fondazione Ri.MED, Palermo, Italy \\ ${ }^{3}$ Section of Pharmacology, Department of Internal Medicine (DiMI) and Center of Excellence for Biomedical Research (CEBR), \\ University of Genova, Genova, Italy \\ ${ }^{4}$ Department of Experimental Medicine (DIMES), University of Genova, Genova, Italy \\ ${ }^{5}$ IRCCS-AOU San Martino-IST, Genova, Italy
}

Correspondence should be addressed to Serena Vella; sevella@ismett.edu

Received 2 August 2016; Accepted 14 September 2016

Academic Editor: Daniele Fanale

Copyright (c) 2016 Serena Vella et al. This is an open access article distributed under the Creative Commons Attribution License, which permits unrestricted use, distribution, and reproduction in any medium, provided the original work is properly cited.

\begin{abstract}
Neuroblastoma (NB) is the most common and aggressive pediatric cancer, characterized by a remarkable phenotypic diversity and high malignancy. The heterogeneous clinical behavior, ranging from spontaneous remission to fatal metastatic disease, is attributable to NB biology and genetics. Despite major advances in therapies, NB is still associated with a high morbidity and mortality. Thus, novel diagnostic, prognostic, and therapeutic approaches are required, mainly to improve treatment outcomes of high-risk NB patients. Among neuroepithelial cancers, NB is the most studied tumor as far as PPAR ligands are concerned. PPAR ligands are endowed with antitumoral effects, mainly acting on cancer stem cells, and constitute a possible add-on therapy to antiblastic drugs, in particular for NB with unfavourable prognosis. While discussing clinical background, this review will provide a synopsis of the major studies about PPAR expression in NB, focusing on the potential beneficial effects of hypoglycemic drugs, thiazolidinediones and metformin, to reduce the occurrence of relapses as well as tumor regrowth in NB patients.
\end{abstract}

\section{Introduction}

(1) Neuroblastoma. Neuroblastoma (NB) is a tumor of the developing sympathetic nervous system observed in early childhood, which is characterized by a broad spectrum of clinical behaviors, ranging from complete regression to death.

NB represents the second most common extracranial malignancy of childhood, accounting for 8 to $10 \%$ of all childhood cancers (NB prevalence is about one case in 7,00010,000 live births) and for approximately $15 \%$ of the pediatric deaths for malignant conditions [1].

The clinical presentation of NB ranges from asymptomatic masses to primary tumors that cause critical illness due to local invasion and/or widely disseminated disease. Most primary NB (65\%) usually present in the abdominal region, often in the adrenal medulla. Other common sites of disease include the neck and head (5\%), chest (20\%), and pelvis (5\%) [1].

NB is a disease of the sympaticoadrenal lineage of the neural crest and originates from neuroblasts in the developing peripheral nervous system [2].

In recent years, it has been suggested that NB tumorigenesis is dependent on the presence of cancer stem cells (CSCs), which have been also isolated from NB cell lines $[3,4]$. CSCs are thought to be also responsible for metastasis and recurrence in NB patients $[5,6]$.

Cellular heterogeneity is a hallmark of NB nodules and the prognosis of these tumors depends on their differentiation levels [7]. Interestingly, cell lines established from several human NB retain similar cellular heterogeneity. 
Biedler et al. described three cell subtypes, often discernible also in NB cell line cultures, based on cell morphology, biochemical features, and growth patterns [8]: (i) N-type (neuroblastic: aggregated, poorly attached, and rounded cells with short neurites); (ii) S-type (substrate-adherent and nonneuronal cells); and (iii) I-type (intermediate: mildly adherent cells, showing marked stem-like traits, representing cancer stem-like cells population, and being thought to originate both S- and N-type cells) [7].

Several studies have shown that these cell types derive from a common precursor and are able to bidirectionally differentiate. This bidirectional conversion between welldefined differentiation lineages of the neural crest has been termed "transdifferentiation" [9].

Because the transdifferentiation process is able to also allow the differentiating of malignant CSCs into benign phenotype, a novel concept in cancer biology was introduced: "induction of differentiation" as possible treatment (e.g., using retinoids to treat $\mathrm{NB}$ and acute promyelocytic leukaemia [10]).

The cause of NB development is still unclear occurring mostly as sporadic disease but also rare (about $1 \%$ of all cases) familial cases were reported [1]. Genomic alterations are associated with NB development and/or progression, many of which have proven to be correlated with clinical outcome. The most widely studied cytogenetic alterations, associated with poor outcome in NB, include $\mathrm{N}$-myc oncogene amplification, loss or rearrangement of the distal portion of the short arm of chromosomes 1 (1p31-term), 3 (3p22), and 11 (11q23), gains of chromosome arm 1q or $17 \mathrm{q}$, and the expression of the TrkB neurotrophin receptor and its ligand [34-38]. Other cytogenetic and molecular abnormalities are likely involved in NB pathogenesis and their identification could be useful for diagnosis, prognosis, and therapy of NB patients.

Traditional NB treatments include surgery, chemotherapy, radiotherapy, and biotherapy [34]. However, the majority of NB patients (50\%) have poor outcomes and relapses, remaining a clinical challenge.

Unfortunately, in many cases, by the time of diagnosis, the disease has usually spread already. In these cases, the mainstay treatment is frequently intensive regimens including combinations of high doses of chemotherapeutics [39] that often are accompanied by unacceptable high toxicities and no long-term improvements. Innovative approaches are therefore needed for this disease. The new treatment protocols for NB currently under investigation consist of targeted radiotherapy and retinoid compounds (to induce terminal differentiation of NB cells), immunological treatment, such as using antidisialoganglioside 2 with or without association with cytokines (GM-CSF, IL-2), antiangiogenics, neurotrophin-signaling inhibitors, proapoptotic agents, allogeneic haemopoietic stem cell transplantation, and new chemotherapeutics [34, 39].

(2) PPARs. Peroxisome proliferator-activated receptors (PPARs) are ligand-activated transcription factors belonging to the nuclear receptor superfamily.
PPARs are activated by fatty acids, eicosanoids, other dietary lipids, and their metabolites, or synthetic ligands [40], which have been pharmacologically used in several diseases, making PPARs attractive therapeutic targets.

There are three PPAR isoforms $(\alpha, \beta / \delta$, and $\gamma)$ which are encoded by separate genes [41] and are expressed during different stages of prenatal development [42].

Through the regulation of the expression of multiple genes [43], PPARs control several physiological processes, including cell proliferation, morphogenesis, differentiation, and cellular homeostasis $[44,45]$, and have been implicated in different human diseases such as hyperlipedimia, diabetes, obesity, inflammation, neurodegenerative disorder, cardiovascular diseases, and cancer [46-49].

Although all PPAR isoforms display a partially overlapping spectrum of activity, essentially as far as the control of lipid and energy metabolism is concerned, they differ in tissue expression pattern and functional roles [50-52].

PPAR- $\alpha$ is predominantly expressed in metabolically active tissues, such as liver, skeletal muscle, heart, intestinal mucosa, brown adipose tissue, adrenal gland, pancreas, and kidney. This receptor regulates catabolism of fatty acids and promotes lipolysis and fatty acid oxidation [53-56].

PPAR- $\alpha$ endogenous ligands (fatty acids and several fattyacid-derived compounds) or synthetic pharmacological agonists (fibrate drugs, WY14643 and GW7647) have been identified [57], and some of them are currently used for the treatment of hypertriglyceridemia and cardiovascular diseases [58].

PPAR- $\beta / \delta$ is ubiquitously expressed particularly in liver, intestine, kidney, abdominal adipose tissue, skeletal muscle, and macrophages. It regulates energy expenditure, participating in fatty acid oxidation and regulating blood cholesterol concentrations and glucose levels $[41,54,59]$.

PPAR- $\beta / \delta$ agonists are prostacyclin PGI2, oleic acid, and synthetic agents, such as GW501516, GW7842, and GW0742, which attenuate hepatic steatosis [60].

PPAR $-\gamma$ is expressed within adipose tissue, the large intestine, spleen, skeletal muscle, liver, pancreas, endothelial cells, immune cells, various cancer cells, and brain [61-63].

It regulates energy storage and has a key role in fatty acid metabolism and glucose homeostasis [55, 64-66], mitochondrial biogenesis, and ROS metabolism [67, 68]. Many lipids, including eicosanoids and the cyclopentenone prostaglandin 15-deoxy- $\Delta 12,14$-prostaglandin J2 (15-deoxyPGJ2), are endogenous PPAR- $\gamma$ ligands, while synthetic agonists include thiazolidinediones (TZDs), GI262570, GW1929, and GW7845 [69]. PPAR- $\gamma$ has been extensively studied as a pharmacological target in several diseases.

TZDs are the best-characterized pharmacological PPAR$\gamma$ agonists, and, among them, pioglitazone and rosiglitazone have been approved by FDA for treatment of type II diabetes [70-72].

In addition, another oral hypoglycemic drug, metformin, which directly improves insulin action, modulating AMPK activity (a key energy regulator), increases PPAR- $\gamma$ mRNA levels [73], acting similarly to rosiglitazone [74]. 


\section{PPARs in Neuroblastoma}

Interestingly, it has been suggested to use PPARs as target for cancer treatment, and several PPAR agonists, in particular acting on PPAR- $\gamma$, represent promising therapeutic tools as antitumoral agents [75]; PPAR- $\gamma$ agonists were reported to inhibit cell growth and to induce apoptosis in several cancer cell lines in vitro and in vivo [76-86], including NB cells $[87,88]$.

All three PPARs isoforms have been identified in NB, although human NB cell lines express PPAR- $\alpha$ (mRNA or proteins) at very low level $[11,89-91]$, and PPAR- $\beta / \delta$ expression data are still incomplete [11, 92]. Conversely, PPAR- $\gamma$ is highly expressed in NB cell lines $[11,12]$ and in primary NB cell cultures [75], being mainly localized in the nuclei rather than in the cytoplasm and being particularly expressed in cells showing ganglionic differentiation [11, 89].

In addition, it has been documented that embryonic rat brain and neural stem cells have higher concentration of PPAR- $\gamma$ than adult rat brain $[42,93]$. In neural stem cells, PPAR- $\gamma$ is involved in the regulation of proliferation and differentiation [94].

Interestingly, PPAR- $\gamma$ expression is correlated to the maturational stage of $\mathrm{NB}$ and therefore to NB patients' outcome [85], and PPAR- $\gamma$ agonists induce NB cell differentiation, inhibiting proliferation, neurite outgrowth, and reducing $\mathrm{N}$ myc levels [11].

2.1. PPARs Agonists in Neuroblastoma. Several studies have assessed the activity of PPAR- $\gamma$ in NB, evaluating the effects of several natural or synthetic ligands on cellular proliferation, apoptosis, and differentiation (Table 1).

15-deoxy- $\Delta 12,14$-prostaglandin J2 (15-deoxy-PGJ2), a high-affinity natural ligand of PPAR- $\gamma$, inhibits in vitro growth and induces apoptosis in NB cells [11-16], through PPAR- $\gamma$-dependent ERK2 activation, although PPAR- $\gamma$-independent effects of 15-deoxy-PGJ2 have been also described [14].

In addition, Rodway et al. have found that the inhibition of NB growth induced by 15-deoxy-PGJ2 can be reduced by the presence of serum lysolipids in the culture medium [14], while Emmans et al. reported that the degree of PPAR activation, due to 15-deoxy-PGJ2, in a NB cell line, is attenuated in the presence of the retinoblastoma protein $(\mathrm{Rb})$ and restored by treatment with the histone deacetylase inhibitor trichostatin A (TSA). The combination treatment with 15deoxy-PGJ2 and TSA enhances the inhibition of NB growth, suggesting a synergistic activity of the two compounds [13]. Furthermore, 15-deoxy-PGJ2 promotes NB cell differentiation, which may be mediated by the p38 MAP kinase activation and the AP-1 signaling pathway [95].

Synthetic PPAR- $\gamma$ ligands have been also tested to contrast NB cell growth.

Han and coworkers firstly evaluated the effect of the synthetic ligand, GW1929, in the NB cell line LA-N-5, and found that this compound induces cell differentiation and inhibits proliferation [11].
GW1929 prodifferentiating effect was shown to be dependent on PPAR- $\gamma$ activation, as demonstrated by the use of specific antagonists [96].

In 2005, Valentiner et al. tested the effects of four TZDs (ciglitazone, pioglitazone, troglitazone, and rosiglitazone) in seven NB cell lines (i.e., Kelly, LAN-1, LAN-5, LS, IMR-32, SK-N-SH, and SH-SY5Y) [17]. All the ligands, in particular ciglitazone and rosiglitazone, inhibited cell proliferation and viability in a dose-dependent manner, with different drug effectiveness among cell lines. Moreover, drug potency was not related to PPAR- $\gamma$ protein amount in NB cell lines, but rather to various cellular conditions associated with the receptor function.

The antiproliferative effect of rosiglitazone was confirmed by the same group in vivo, in a metastatic xenograft mouse model [18], although its antitumor effect was very limited.

Ciglitazone was also used in association with 15-deoxyPGJ2 to overexpress Rb protein and inhibit PPAR- $\gamma$ activity, reducing NB cell growth [13].

Servidei et al. tested 15-deoxy-PGJ2 and rosiglitazone on $8 \mathrm{NB}$ cell lines, with different phenotypes, including $\mathrm{N}$ - and S-types [12]. The two PPAR- $\gamma$ ligands inhibit cell growth in all cell lines, and the sensitivity seems to be more associated with the cell phenotype than with PPAR- $\gamma$ expression: indeed, $\mathrm{N}$-type cells are more susceptible to treatment than S-type cells, partly because of their higher capability of undergoing apoptosis.

Many studies have documented that the inhibitory effects of TZDs on neuroblastoma cell growth are partially due to an increase of apoptosis. Indeed, troglitazone induced PPAR$\gamma$-dependent apoptosis in NB-1 cells [19] and in SHEP NB [20]. In contrast, only two studies, to our knowledge, reported antiapoptotic effects of rosiglitazone which protected NB cells subjected to $\mathrm{MPP}^{+}$-induced mitochondrial injury reducing ROS production [21, 22].

Proapoptotic effects of rosiglitazone were also reported [23]. This PPAR- $\gamma$ ligand significantly inhibits cell adhesion and invasiveness and induces apoptosis, more effectively in SK-N-AS than in SH-SY5Y cell lines. The distinct response of the two NB cell lines is likely due to a reduced phosphorylation of PPAR- $\gamma$ and consequently its increased activity in SK-N-AS cells. Cellai and colleagues also evaluated the in vivo effect of TZDs in NB xenograft models, confirming their previous in vitro observations [24]. Indeed rosiglitazone ( $150 \mathrm{mg} / \mathrm{kg} /$ day) for 4 weeks significantly reduced tumor growth (-70\%) as compared to control mice [24].

In addition, rosiglitazone induces differentiation, increasing density of dendritic spines in rat primary cortical neurons [25].

Moreover, in neural stem cells (NSC) from adult mammalian brain, pioglitazone and rosiglitazone directly regulate proliferation, differentiation, and migration [26].

Accordingly, Miglio et al. described the effects of pioglitazone on SH-SY5Y NB cells, in which this agonist promotes differentiation and outgrowth of cell processes, in a dosedependent manner [27]. In 2014, Chiang et al. evaluated the effects of rosiglitazone in the mouse NB Neuro 2a (N2A) cell line. This agonist stimulates neurite outgrowth and 
TABLE 1: Preclinical and experimental studies on PPAR agonists in neuroblastoma.

\begin{tabular}{|c|c|c|c|c|c|c|}
\hline Drug/s & Reference/s & Year & Target & $\begin{array}{l}\text { Study } \\
\text { types }\end{array}$ & Cell lines/animal model & Effects \\
\hline 15-deoxy-PGJ2 & {$[11-16]$} & $\begin{array}{l}2001 \\
2003 \\
2004\end{array}$ & PPAR- $\gamma$ & In vitro & $\begin{array}{l}\text { NB cell lines and primary } \\
\text { cultures of cortical neurons }\end{array}$ & $\begin{array}{l}\text { Inhibition of growth and } \\
\text { apoptosis induction, through } \\
\text { PPAR- } \gamma \text {-dependent and } \\
\text { PPAR- } \gamma \text {-independent effects. }\end{array}$ \\
\hline GW1929 & {$[11]$} & 2001 & PPAR- $\gamma$ & In vitro & LA-N-5 & $\begin{array}{l}\text { Prodifferentiating effect and } \\
\text { inhibition of proliferation. }\end{array}$ \\
\hline $\begin{array}{l}\text { Rosiglitazone } \\
\text { and } \\
\text { 15-deoxy-PGJ2 }\end{array}$ & {$[12]$} & 2004 & PPAR- $\gamma$ & In vitro & $\begin{array}{c}\text { SH-SY5Y, SH-EP1, SK-N-AS, } \\
\text { SK-N-FI, LA-N-5, SMS-KCNR, } \\
\text { SK-N-DZ, and LA-N-1 }\end{array}$ & $\begin{array}{l}\text { Inhibition of cell growth with } \\
\text { different sensitivity related to the } \\
\text { cell phenotype. }\end{array}$ \\
\hline $\begin{array}{l}\text { Ciglitazone and } \\
\text { 15-deoxy-PGJ2 }\end{array}$ & {$[13]$} & 2004 & PPAR- $\gamma$ & In vitro & $\begin{array}{l}\text { SK-N-AS, IMR-32, SK-N-SH, } \\
\text { and ND-7 }\end{array}$ & $\begin{array}{l}\text { Overexpression of Rb protein } \\
\text { and inhibition of PPAR- } \gamma \\
\text { activity, reducing NB cell growth. }\end{array}$ \\
\hline $\begin{array}{l}\text { Ciglitazone, } \\
\text { pioglitazone, } \\
\text { troglitazone, } \\
\text { and } \\
\text { rosiglitazone }\end{array}$ & {$[17]$} & 2005 & PPAR- $\gamma$ & In vitro & $\begin{array}{l}\text { Kelly, LA-N-1, LA-N-5, LS, } \\
\text { IMR-32, SK-N-SH, and SH-SY5Y }\end{array}$ & $\begin{array}{l}\text { Inhibition of cell proliferation } \\
\text { and viability in a dose-dependent } \\
\text { manner. }\end{array}$ \\
\hline Rosiglitazone & {$[18]$} & 2010 & PPAR- $\gamma$ & In vivo & $\begin{array}{c}\text { SK-N-SH xenograft NB mouse } \\
\text { model }\end{array}$ & Inhibition of tumor growth. \\
\hline Troglitazone & {$[19]$} & 2002 & PPAR- $\gamma$ & In vitro & NB-1 cell line & $\begin{array}{l}\text { Increase of PPAR- } \gamma \text {-dependent } \\
\text { apoptosis. }\end{array}$ \\
\hline Troglitazone & {$[20]$} & 2006 & PPAR- $\gamma$ & In vitro & SHEP NB cell line & $\begin{array}{l}\text { Increase of PPAR- } \gamma \text {-dependent } \\
\text { apoptosis. }\end{array}$ \\
\hline Rosiglitazone & {$[21,22]$} & $\begin{array}{l}2006 \\
2007\end{array}$ & PPAR- $\gamma$ & In vitro & SH-SY5Y cell line & $\begin{array}{l}\text { Antiapoptotic effects of } \\
\text { rosiglitazone which protected NB } \\
\text { cells subjected to } \mathrm{MPP}^{+} \text {-induced } \\
\text { mitochondrial injury reducing } \\
\text { ROS production. }\end{array}$ \\
\hline Rosiglitazone & [23] & 2006 & PPAR- $\gamma$ & In vitro & SK-N-AS and SH-SY5Y cell lines & $\begin{array}{l}\text { Inhibition of cell adhesion, } \\
\text { invasiveness, and proapoptotic } \\
\text { effects. }\end{array}$ \\
\hline Rosiglitazone & {$[24]$} & 2010 & PPAR- $\gamma$ & In vivo & $\begin{array}{l}\text { SK-N-AS xenograft NB mouse } \\
\text { model }\end{array}$ & $\begin{array}{l}\text { Significant decrease of tumor } \\
\text { growth }(-70 \%) \text { as compared to } \\
\text { control mice. }\end{array}$ \\
\hline Rosiglitazone & {$[25]$} & 2008 & PPAR- $\gamma$ & In vitro & Rat primary cortical neurons & $\begin{array}{l}\text { Induction of cell differentiation, } \\
\text { increasing dendritic spine } \\
\text { density. }\end{array}$ \\
\hline $\begin{array}{l}\text { Pioglitazone and } \\
\text { rosiglitazone }\end{array}$ & {$[26]$} & 2011 & PPAR- $\gamma$ & $\begin{array}{l}\text { Both in } \\
\text { vitro and } \\
\text { in vivo }\end{array}$ & Adult male Wistar rats & $\begin{array}{l}\text { Induction of proliferation, } \\
\text { differentiation, and migration of } \\
\text { neural stem cells in vitro and in } \\
\text { vivo. }\end{array}$ \\
\hline Pioglitazone & {$[27]$} & 2009 & PPAR- $\gamma$ & In vitro & SH-SY5Y cell line & $\begin{array}{l}\text { Induction of differentiation and } \\
\text { neurite outgrowth, promoting } \\
\text { differentiation and outgrowth of } \\
\text { cell processes. }\end{array}$ \\
\hline Rosiglitazone & {$[28]$} & 2014 & PPAR- $\gamma$ & In vitro & $\begin{array}{l}\text { Mouse NB Neuro 2a (N2A) cell } \\
\text { line }\end{array}$ & $\begin{array}{l}\text { Stimulation of neurite outgrowth } \\
\text { and significant increase of the } \\
\text { population of neurite-bearing } \\
\text { cells, via PPAR- } \gamma \text { pathway. }\end{array}$ \\
\hline $\begin{array}{l}\text { Oleic acid or } \\
\text { GW0742 }\end{array}$ & {$[29]$} & 2007 & PPAR- $\beta / \delta$ & In vitro & SH-NH-5YSY cell line & $\begin{array}{l}\text { Induction of G1 cell cycle arrest, } \\
\text { reduction of cell migration and } \\
\text { invasiveness, and an increase of } \\
\text { neuronal differentiation. }\end{array}$ \\
\hline
\end{tabular}


significantly increases the population of neurite-bearing cells, via PPAR- $\gamma$ pathway [28].

All these observations are in agreement with previous findings indicating that PPAR- $\gamma$ activation contributes to neuronal differentiation [11, 94-99].

While PPAR- $\gamma$ activation mainly results in apoptosis promotion in proliferating cells, PPAR- $\beta / \delta$ natural (i.e., oleic acid) and synthetic (i.e., GW0742) agonists induce G1 cell cycle arrest, reduce cell migration and invasiveness, and increase neuronal differentiation in SH-NH-5YSY [29].

In summary, all these results suggest the possible use of PPAR agonists as novel therapy for NB, but to date clinical trials are not yet underway (http://www.who.int/topics/clinical_ trials/en/).

2.2. Metformin and Neuroblastoma. Beyond TZDs, metformin is another hypoglycemic drug able to modulate PPAR expression or activity, although these effects are rather cell specific and mainly indirectly mediated by the activation of AMPK.

Metformin is biguanide with a well-known safety profile, mainly used as oral antidiabetic drug [100, 101], whose promising anticancer activity was recently discovered [102]. It is well-documented that metformin inhibits tumor growth in in vitro and in vivo preclinical cancer models [103-110], and various human clinical trials are in progress (WHO International Clinical Trials Registry Platform, http://www.who.int/ topics/clinical_trials/en/).

In particular, metformin seems to selectively affect cancer stem cell survival, inhibiting cancer metastases and thus represents a good potential adjuvant agent for chemotherapy (as reviewed by [111]).

However, the molecular mechanisms of action of metformin are still not completely defined, although it seems that the antiproliferative mechanisms induced by this drug are at least partially diverging from those regulating glucose homeostasis. While the latter is mainly dependent on the AMPK activation, the antitumor activity of metformin is mediated by inhibition of AKT/mTOR (also involving AMPK), the inhibition of TK activity, or the regulation of chloride channels [112-116].

As far as the effects of metformin on PPAR activity are concerned, several studies were performed but the results are extremely dependent on the receptor subtype and the cells analyzed. For example, metformin increased PPAR- $\beta / \delta$ expression in muscle cells and activity in endothelial cells $[117,118]$, reducing the effects of ER stress and increasing the bioavailability of nitric oxide [119]. On the other hand, metformin counteracts antiosteogenic PPAR- $\gamma$ activation by rosiglitazone in bone marrow progenitor cells [120] and both PPAR $-\gamma$ and PPAR- $\alpha$ activity in hepatoma cells [121]. Finally, a PPAR- $\alpha$ activation role of metformin was identified to increase GLP-1 receptor levels [122].

However, although demonstrated in several models, the role of the modulation of PPAR expression and/or activity in the antiproliferative effects of metformin in neuroblastoma has not been addressed yet.

The effect of metformin on NB was firstly demonstrated by our groups [30].
We reported that the effects of metformin treatment in human SKNBE2 and SH-SY5Y NB cell lines are a significant reduction in the proliferation rate and cell viability, due to inhibition of AKT phosphorylation and an increased cell death, via apoptosis-independent pathways. These effects were more pronounced in SKNBE2, which are less differentiated, highly proliferative cells than SH-SY5Y cells. Notably, metformin effects were different depending on the differentiating stimuli, being abolished by retinoic acid, but were potentiated by overexpression of NDM29, a noncoding RNA affecting NB malignancy, although both conditions were characterized by a neuron-like differentiated phenotype [30, 123-128].

These in vitro results are in agreement with those of Kumar and coworkers who evaluated the antitumor activity of metformin against neuroblastoma in vivo [31]. Oral administration of metformin, in both SH-SY5Y and SK$\mathrm{N}-\mathrm{BE}$ xenograft NB mouse models, significantly inhibited the growth of the tumors. NB cell viability is reduced by metformin, which also interferes with spheroid formation in 3D cultures, confirming that its antitumor effect could also involve the inhibition of CSC self-renewal. Moreover, in this study, it was confirmed that SKNBE2 cells are more susceptible to metformin than SH-SY5Y cells. In addition, studying the underlying signaling mechanisms, they highlighted that a modulation of Rho-GTPases and MAP kinase activation mediate metformin effects on NB cell survival.

In the same year, Vujic et al. successfully used metformin to inhibit cell proliferation and induce apoptosis in NRAS mutant NB cell lines (SK-N-AS and CHP-212), in which NRAS signaling is constitutively active through the PI3K/ AKT/mTOR pathway [32].

In 2015, Mouhieddine and colleagues found that metformin reduces proliferation rate, viability, and invasive potential of NB cell lines SH-SY5Y [33].

Interestingly, focusing on metformin effect on stem cell population within a $3 \mathrm{D}$ culture model, these authors reported that this drug is able to decrease, but not abolish, cell sphereforming ability, significantly targeting and reducing cancer stem/progenitor cell population and thus possibly preventing recurrence.

Notably, metformin also reduces MMP-2, a protein involved in extracellular matrix degradation, favoring metastasis and cancer progression [33].

Thanks to the highly selective and cytotoxic effects of metformin on NB cells and on stem cell population in particular (Table 2), these studies suggest that high-risk NB patients could have great benefit by using metformin in terms of increasing disease prognosis and propose that this drug can also be used as a novel therapeutic agent against neuroblastoma. However, at the moment, there are no clinical trials evaluating metformin efficacy for the treatment of NB (WHO International Clinical Trials Registry Platform, http:// www.who.int/topics/clinical_trials/en/).

\section{Conclusion}

Despite advances in standard therapeutic protocols, the prognosis of NB has not gained significant progress, especially 
TABLE 2: Studies on metformin treatment to date in neuroblastoma.

\begin{tabular}{|c|c|c|c|c|}
\hline Reference/s & Year & Study types & Cell lines/animal model & Effects \\
\hline$[30]$ & 2014 & In vitro & $\begin{array}{l}\text { SKNBE2 and SH-SY5Y cell } \\
\text { lines }\end{array}$ & $\begin{array}{c}\text { Significant reduction in the proliferation rate and cell } \\
\text { viability, due to inhibition of AKT phosphorylation, } \\
\text { and an increased cell death, via apoptosis-independent } \\
\text { pathways. }\end{array}$ \\
\hline$[31]$ & 2014 & In vivo & $\begin{array}{l}\text { SH-SY5Y and SK-N-BE } \\
\text { xenograft NB mouse } \\
\text { models }\end{array}$ & $\begin{array}{l}\text { Significant inhibition of tumor growth and NB cell } \\
\text { viability, interfering with spheroid formation in 3D } \\
\text { cultures. Modulation of Rho-GTPases and AMPK } \\
\text { activation mediate metformin effects on NB cell } \\
\text { survival. }\end{array}$ \\
\hline [32] & 2015 & In vitro & $\begin{array}{l}\text { SK-N-AS and CHP-212 cell } \\
\text { lines }\end{array}$ & $\begin{array}{l}\text { Inhibition of cell proliferation and induction of } \\
\text { apoptosis. }\end{array}$ \\
\hline [33] & 2015 & In vitro & SH-SY5Y cell line & $\begin{array}{c}\text { Reduction of proliferation rate, viability, and invasive } \\
\text { potential. }\end{array}$ \\
\hline
\end{tabular}

concerning the rates of metastasis, the incidence of recurrences, and the long-term survival, which are all correlated with the presence of CSCs.

Recently, many groups focused their attention on PPARs, suggesting the use of several PPAR agonists, currently used as hypoglycemic drugs, for NB treatment. Interestingly, many in vitro and in vivo studies reported the successful use of PPAR agonists, and in particular of TZDs, in the inhibition of NB cell proliferation and tumor growth, in the induction of cell death, and in the promotion of cell differentiation. These effects are PPAR-dependent, even if some PPAR-independent effects have been also described. Notably, PPAR agonists also reduce the viability of CSCs, the tumor cell subpopulation responsible of NB recurrence. Similar results were obtained with another hypoglycemic drug, metformin, which acts also via the modulation PPAR activity. In the future, it will be important to examine the contribution of PPARs in the antiproliferative activity of metformin and the possible synergistic effect with known or novel selective PPAR agonists.

Although further studies in vitro as well as in vivo are needed, these hypoglycemic drugs may represent realistic new therapeutic approaches to be used as good adjuvant chemotherapeutic agents in NB treatment.

\section{Competing Interests}

The authors declare no competing interests.

\section{Authors' Contributions}

Tullio Florio and Aldo Pagano equally contributed to the study and should be considered as senior authors.

\section{Acknowledgments}

The financial support of Compagnia di San Paolo is gratefully acknowledged. Aldo Pagano was supported by the IRCCSAOU San Martino-IST, Genoa, Italy (Progetto $5 \times 1000$ ), by the University of Genoa, Genoa, Italy (Progetti di Ricerca di Ateneo, 2013), and by the Associazione Italiana per la Lotta al Neuroblastoma/Fondazione Neuroblastoma (Genoa, Italy).

\section{References}

[1] J. R. Park, A. Eggert, and H. Caron, "Neuroblastoma: biology, prognosis, and treatment," Hematology/Oncology Clinics of North America, vol. 24, no. 1, pp. 65-86, 2010.

[2] J. C. Hoehner, C. Gestblom, F. Hedborg, B. Sandstedt, L. Olsen, and S. Påhlman, "A developmental model of neuroblastoma: differentiating stroma-poor tumors' progress along an extraadrenal chromaffin lineage," Laboratory Investigation, vol. 75, no. 5, pp. 659-675, 1996.

[3] H. Komuro, R. Saihara, M. Shinya et al., "Identification of side population cells (stem-like cell population) in pediatric solid tumor cell lines," Journal of Pediatric Surgery, vol. 42, no. 12, pp. 2040-2045, 2007.

[4] R. A. Ross and B. A. Spengler, "Human neuroblastoma stem cells," Seminars in Cancer Biology, vol. 17, no. 3, pp. 241-247, 2007.

[5] J. E. Visvader, "Cells of origin in cancer," Nature, vol. 469, no. 7330, pp. 314-322, 2011.

[6] J. A. Magee, E. Piskounova, and S. J. Morrison, "Cancer stem cells: impact, heterogeneity, and uncertainty," Cancer Cell, vol. 21, no. 3, pp. 283-296, 2012.

[7] J. D. Walton, D. R. Kattan, S. K. Thomas et al., "Characteristics of stem cells from human neuroblastoma cell lines and in tumors," Neoplasia, vol. 6, no. 6, pp. 838-845, 2004.

[8] J. L. Biedler, L. Helson, and B. A. Spengler, "Morphology and growth, tumorigenicity, and cytogenetics of human neuroblastoma cells in continuous culture," Cancer Research, vol. 33, no. 11, pp. 2643-2652, 1973.

[9] V. Ciccarone, B. A. Spengler, M. B. Meyers, J. L. Biedler, and R. A. Ross, "Phenotypic diversification in human neuroblastoma cells: expression of distinct neural crest lineages," Cancer Research, vol. 49, no. 1, pp. 219-225, 1989.

[10] S. Påhlman, M.-T. Stockhausen, E. Fredlund, and H. Axelson, "Notch signaling in neuroblastoma," Seminars in Cancer Biology, vol. 14, no. 5, pp. 365-373, 2004.

[11] S. W. Han, M. E. Greene, J. Pitts, R. K. Wada, and N. Sidell, "Novel expression and function of peroxisome proliferatoractivated receptor gamma (PPAR $\gamma)$ in human neuroblastoma cells," Clinical Cancer Research, vol. 7, no. 1, pp. 98-104, 2001.

[12] T. Servidei, R. Morosetti, C. Ferlini et al., "The cellular response to PPARgamma ligands is related to the phenotype of neuroblastoma cell lines," Oncology Research, vol. 14, no. 7-8, pp. 345354, 2004. 
[13] V. C. Emmans, H. A. Rodway, A. N. Hunt, and K. A. Lillycrop, "Regulation of cellular processes by PPAR $\gamma$ ligands in neuroblastoma cells is modulated by the level of retinoblastoma protein expression," Biochemical Society Transactions, vol. 32, no. 5, pp. 840-842, 2004.

[14] H. A. Rodway, A. N. Hunt, J. A. Kohler, A. D. Postle, and K. A. Lillycrop, "Lysophosphatidic acid attenuates the cytotoxic effects and degree of peroxisome proliferator-activated receptor $\gamma$ activation induced by 15 -deoxy $\Delta^{12,14}$-prostaglandin $\mathrm{J}_{2}$ in neuroblastoma cells," Biochemical Journal, vol. 382, no. 1, pp. 8391, 2004.

[15] E. U. N. J. Kim, K. S. I. S. Park, S. Y. O. O. Y. Chung et al., "Peroxisome proliferator-activated receptor- $\gamma$ activator 15-deoxy- $\Delta^{12,14}$-prostaglandin $\mathrm{J}_{2}$ inhibits neuroblastoma cell growth through induction of apoptosis: association with extracellular signal-regulated kinase signal pathway," Journal of Pharmacology and Experimental Therapeutics, vol. 307, no. 2, pp. 505-517, 2003.

[16] T. T. Rohn, S. M. Wong, C. W. Cotman, and D. H. Cribbs, "15deoxy-delta12,14-prostaglandin J2, a specific ligand for peroxisome proliferator-activated receptor-gamma, induces neuronal apoptosis," Journal of Controlled Release, vol. 12, no. 4, pp. 839$843,2001$.

[17] U. Valentiner, M. Carlsson, R. Erttmann, H. Hildebrandt, and U. Schumacher, "Ligands for the peroxisome proliferatoractivated receptor- $\gamma$ have inhibitory effects on growth of human neuroblastoma cells in vitro," Toxicology, vol. 213, no. 1-2, pp. 157-168, 2005.

[18] N. Krieger-Hinck, U. Schumacher, A. Müller, and U. Valentiner, "The effect of the PPAR- $\gamma$ agonist rosiglitazone on neuroblastoma SK-N-SH cells in a metastatic xenograft mouse model," Oncology Research, vol. 18, no. 8, pp. 387-393, 2010.

[19] M. Kato, T. Nagaya, M. Fujieda, K. Saito, J. Yoshida, and H. Seo, "Expression of PPAR $\gamma$ and its ligand-dependent growth inhibition in human brain tumor cell lines," Japanese Journal of Cancer Research, vol. 93, no. 6, pp. 660-666, 2002.

[20] K. Schultze, B. Böck, A. Eckert et al., “Troglitazone sensitizes tumor cells to TRAIL-induced apoptosis via down-regulation of FLIP and Survivin," Apoptosis, vol. 11, no. 9, pp. 1503-1512, 2006.

[21] T. W. Jung, J. Y. Lee, W. S. Shim et al., "Rosiglitazone protects human neuroblastoma SH-SY5Y cells against $\mathrm{MPP}^{+}$induced cytotoxicity via inhibition of mitochondrial dysfunction and ROS production," Journal of the Neurological Sciences, vol. 253, no. 1-2, pp. 53-60, 2007.

[22] T. W. Jung, J. Y. Lee, W. S. Shim et al., "Rosiglitazone protects human neuroblastoma SH-SY5Y cells against acetaldehydeinduced cytotoxicity," Biochemical and Biophysical Research Communications, vol. 340, no. 1, pp. 221-227, 2006.

[23] I. Cellai, S. Benvenuti, P. Luciani et al., "Antineoplastic effects of rosiglitazone and PPAR $\gamma$ transactivation in neuroblastoma cells," British Journal of Cancer, vol. 95, no. 7, pp. 879-888, 2006.

[24] I. Cellai, G. Petrangolini, M. Tortoreto et al., "In vivo effects of rosiglitazone in a human neuroblastoma xenograft," British Journal of Cancer, vol. 102, no. 4, pp. 685-692, 2010.

[25] J. Brodbeck, M. E. Balestra, A. M. Saunders, A. D. Roses, R. W. Mahley, and Y. Huang, "Rosiglitazone increases dendritic spine density and rescues spine loss caused by apolipoprotein E4 in primary cortical neurons," Proceedings of the National Academy of Sciences of the United States of America, vol. 105, no. 4, pp. 1343-1346, 2008.
[26] J. A. Morales-Garcia, R. Luna-Medina, C. Alfaro-Cervello et al., "Peroxisome proliferator-activated receptor $\gamma$ ligands regulate neural stem cell proliferation and differentiation in vitro and in vivo," Glia, vol. 59, no. 2, pp. 293-307, 2011.

[27] G. Miglio, L. Rattazzi, A. C. Rosa, and R. Fantozzi, "PPAR $\gamma$ stimulation promotes neurite outgrowth in SH-SY5Y human neuroblastoma cells," Neuroscience Letters, vol. 454, no. 2, pp. 134-138, 2009.

[28] M.-C. Chiang, Y.-C. Cheng, H.-M. Chen, Y.-J. Liang, and C.-H. Yen, "Rosiglitazone promotes neurite outgrowth and mitochondrial function in N2A cells via PPARgamma pathway," Mitochondrion, vol. 14, no. 1, pp. 7-17, 2014.

[29] S. Di Loreto, B. D’Angelo, M. A. D'Amico et al., "PPAR $\beta$ agonists trigger neuronal differentiation in the human neuroblastoma cell line SH-SY5Y," Journal of Cellular Physiology, vol. 211, no. 3, pp. 837-847, 2007.

[30] D. Costa, A. Gigoni, R. Würth, R. Cancedda, T. Florio, and A. Pagano, "Metformin inhibition of neuroblastoma cell proliferation is differently modulated by cell differentiation induced by retinoic acid or overexpression of NDM29 non-coding RNA," Cancer Cell International, vol. 14, article 59, 2014.

[31] A. Kumar, N. Al-Sammarraie, D. J. DiPette, and U. S. Singh, "Metformin impairs Rho GTPase signaling to induce apoptosis in neuroblastoma cells and inhibits growth of tumors in the xenograft mouse model of neuroblastoma," Oncotarget, vol. 5, no. 22, pp. 11709-11722, 2014.

[32] I. Vujic, M. Sanlorenzo, C. Posch et al., "Metformin and trametinib have synergistic effects on cell viability and tumor growth in NRAS mutant cancer," Oncotarget, vol. 6, no. 2, pp. 969-978, 2015.

[33] T. H. Mouhieddine, A. Nokkari, M. M. Itani et al., "Metformin and ara-a effectively suppress brain cancer by targeting cancer stem/progenitor cells," Frontiers in Neuroscience, vol. 9, article 442, 2015.

[34] J. M. Maris, M. D. Hogarty, R. Bagatell, and S. L. Cohn, "Neuroblastoma," The Lancet, vol. 369, no. 9579, pp. 2106-2120, 2007.

[35] G. M. Brodeur, "Neuroblastoma: biological insights into a clinical enigma," Nature Reviews Cancer, vol. 3, no. 3, pp. 203216, 2003.

[36] N. Van Roy, G. Laureys, N. C. Cheng et al., "1;17 Translocations and other chromosome 17 rearrangements in human primary neuroblastoma tumors and cell lines," Genes, Chromosomes and Cancer, vol. 10, no. 2, pp. 103-114, 1994.

[37] C. T. Fong, N. C. Dracopoli, P. S. White et al., "Loss of heterozygosity for the short arm of chromosome 1 in human neuroblastomas: correlation with N-myc amplification," Proceedings of the National Academy of Sciences of the United States of America, vol. 86, no. 10, pp. 3753-3757, 1989.

[38] C. Thiele, "Neuroblastoma cell lines," in Human Cell Culture, pp. 21-53, Kluwer Academic, Dordrecht, Netherlands, 1998.

[39] S. Modak and N.-K. V. Cheung, "Neuroblastoma: therapeutic strategies for a clinical enigma," Cancer Treatment Reviews, vol. 36, no. 4, pp. 307-317, 2010.

[40] C. Blanquart, O. Barbier, J. C. Fruchart, B. Staels, and C. Glineur, "Peroxisome proliferator-activated receptors: regulation of transcriptional activities and roles in inflammation," Journal of Steroid Biochemistry and Molecular Biology, vol. 85, no. 2-5, pp. 267-273, 2003.

[41] J. Berger and D. E. Moller, "The mechanisms of action of PPARs," Annual Review of Medicine, vol. 53, pp. 409-435, 2002. 
[42] O. Braissant and W. Wahli, "Differential expression of peroxisome proliferator-activated receptor- $\alpha,-\beta$, and $-\gamma$ during rat embryonic development," Endocrinology, vol. 139, no. 6, pp. 2748-2754, 1998.

[43] I. Issemann and S. Green, "Activation of a member of the steroid hormone receptor superfamily by peroxisome proliferators," Nature, vol. 347, no. 6294, pp. 645-650, 1990.

[44] W. Ahmed, O. Ziouzenkova, J. Brown et al., "PPARs and their metabolic modulation: new mechanisms for transcriptional regulation?" Journal of Internal Medicine, vol. 262, no. 2, pp. 184-198, 2007.

[45] P. Escher and W. Wahli, "Peroxisome proliferator-activated receptors: insight into multiple cellular functions," Mutation Research/Fundamental and Molecular Mechanisms of Mutagenesis, vol. 448, no. 2, pp. 121-138, 2000.

[46] J. P. Berger, T. E. Akiyama, and P. T. Meinke, "PPARs: therapeutic targets for metabolic disease," Trends in Pharmacological Sciences, vol. 26, no. 5, pp. 244-251, 2005.

[47] S. J. Roberts-Thomson, "Peroxisome proliferator-activated receptors in tumorigenesis: targets of tumour promotion and treatment," Immunology and Cell Biology, vol. 78, no. 4, pp. 436441, 2000.

[48] J. Plutzky, "PPARs as therapeutic targets: reverse cardiology?" Science, vol. 302, no. 5644, pp. 406-407, 2003.

[49] P. Balakumar, M. Rose, S. S. Ganti, P. Krishan, and M. Singh, "PPAR dual agonists: are they opening Pandora's Box?" Pharmacological Research, vol. 56, no. 2, pp. 91-98, 2007.

[50] C. Diradourian, J. Girard, and J.-P. Pégorier, "Phosphorylation of PPARs: from molecular characterization to physiological relevance," Biochimie, vol. 87, no. 1, pp. 33-38, 2005.

[51] S. Tyagi, P. Gupta, A. S. Saini, C. Kaushal, and S. Sharma, "The peroxisome proliferator-activated receptor: a family of nuclear receptors role in various diseases," Journal of Advanced Pharmaceutical Technology and Research, vol. 2, no. 4, pp. 236240, 2011.

[52] E. Boitier, J.-C. Gautier, and R. Roberts, "Advances in understanding the regulation of apoptosis and mitosis by peroxisomeproliferator activated receptors in pre-clinical models: Relevance for human health and disease," Comparative Hepatology, vol. 2, article no. 3, 2003.

[53] S. Neschen, K. Morino, J. Dong et al., "n-3 Fatty acids preserve insulin sensitivity in vivo in a peroxisome proliferator-activated receptor- $\alpha$-dependent manner," Diabetes, vol. 56, no. 4, pp. 1034-1041, 2007.

[54] P. Delerive, C. Furman, E. Teissier, J.-C. Fruchart, P. Duriez, and B. Staels, "Oxidized phospholipids activate PPAR $\alpha$ in a phospholipase A2-dependent manner," FEBS Letters, vol. 471, no. 1, pp. 34-38, 2000.

[55] S. A. Kliewer, S. S. Sundseth, S. A. Jones et al., "Fatty acids and eicosanoids regulate gene expression through direct interactions with peroxisome proliferator-activated receptors $\alpha$ and $\gamma$," Proceedings of the National Academy of Sciences of the United States of America, vol. 94, no. 9, pp. 4318-4323, 1997.

[56] J. Lo Verme, J. Fu, G. Astarita et al., "The nuclear receptor peroxisome proliferator-activated receptor- $\alpha$ mediates the antiinflammatory actions of palmitoylethanolamide," Molecular Pharmacology, vol. 67, no. 1, pp. 15-19, 2005.

[57] C. W. Park, Y. Zhang, X. Zhang et al., "PPAR $\alpha$ agonist fenofibrate improves diabetic nephropathy in db/db mic," Kidney International, vol. 69, no. 9, pp. 1511-1517, 2006.
[58] W. Linz, P. Wohlfart, M. Baader et al., "The peroxisome proliferator-activated receptor- $\alpha$ (PPAR- $\alpha$ ) agonist, AVE8134, attenuates the progression of heart failure and increases survival in rats," Acta Pharmacologica Sinica, vol. 30, no. 7, pp. 935-946, 2009.

[59] Y.-X. Wang, C.-H. Lee, S. Tiep et al., "Peroxisome-proliferatoractivated receptor $\delta$ activates fat metabolism to prevent obesity," Cell, vol. 113, no. 2, pp. 159-170, 2003.

[60] M. Y. Lee, R. Choi, H. M. Kim et al., "Peroxisome proliferatoractivated receptor $\delta$ agonist attenuates hepatic steatosis by anti-inflammatory mechanism," Experimental \& Molecular Medicine, vol. 44, no. 10, pp. 578-585, 2012.

[61] A. Vidal-Puig, M. Jimenez-Liñan, B. B. Lowell et al., "Regulation of PPAR $\gamma$ gene expression by nutrition and obesity in rodents," The Journal of Clinical Investigation, vol. 97, no. 11, pp. 25532561, 1996.

[62] P. Tontonoz, L. Nagy, J. G. A. Alvarez, V. A. Thomazy, and R. M. Evans, "PPAR $\gamma$ promotes monocyte/macrophage differentiation and uptake of oxidized LDL," Cell, vol. 93, no. 2, pp. 241252, 1998.

[63] M. Kiaei, K. Kipiani, J. Chen, N. Y. Calingasan, and M. F. Beal, "Peroxisome proliferator-activated receptor-gamma agonist extends survival in transgenic mouse model of amyotrophic lateral sclerosis," Experimental Neurology, vol. 191, no. 2, pp. 331336, 2005.

[64] S.-H. Sheu, T. Kaya, D. J. Waxman, and S. Vajda, "Exploring the binding site structure of the PPAR $\gamma$ ligand-binding domain by computational solvent mapping," Biochemistry, vol. 44, no. 4, pp. 1193-1209, 2005.

[65] M. Lehrke and M. A. Lazar, “The many faces of PPAR $\gamma$," Cell, vol. 123, no. 6, pp. 993-999, 2005.

[66] G. Medina-Gomez, S. L. Gray, L. Yetukuri et al., "PPAR gamma 2 prevents lipotoxicity by controlling adipose tissue expandability and peripheral lipid metabolism," PLoS Genetics, vol. 3, no. 4, pp. 634-647, 2007.

[67] Z. Wu, P. Puigserver, U. Andersson et al., "Mechanisms controlling mitochondrial biogenesis and respiration through the thermogenic coactivator PGC-1," Cell, vol. 98, no. 1, pp. 115-124, 1999.

[68] D. P. Kelly and R. C. Scarpulla, "Transcriptional regulatory circuits controlling mitochondrial biogenesis and function," Genes and Development, vol. 18, no. 4, pp. 357-368, 2004.

[69] T. M. Larsen, S. Toubro, and A. Astrup, "PPARgamma agonists in the treatment of type II diabetes: is increased fatness commensurate with long-term efficacy?" International Journal of Obesity, vol. 27, no. 2, pp. 147-161, 2003.

[70] B. Richter, E. Bandeira-Echtler, K. Bergerhoff, C. Clar, and S. H. Ebrahim, "Rosiglitazone for type 2 diabetes mellitus," Cochrane Database of Systematic Reviews, no. 3, Article ID CD006063, 2007.

[71] J. van Wijk, B. Coll, M. C. Cabezas et al., "Rosiglitazone modulates fasting and post-prandial paraoxonase 1 activity in type 2 diabetic patients," Clinical and Experimental Pharmacology and Physiology, vol. 33, no. 12, pp. 1134-1137, 2006.

[72] A. Galli, T. Mello, E. Ceni, E. Surrenti, and C. Surrenti, "The potential of antidiabetic thiazolidinediones for anticancer therapy," Expert Opinion on Investigational Drugs, vol. 15, no. 9, pp. 1039-1049, 2006. 
[73] E. M. Elia, C. Pustovrh, S. Amalfi, L. Devoto, and A. B. Motta, "Link between metformin and the peroxisome proliferatoractivated receptor $\gamma$ pathway in the uterine tissue of hyperandrogenized prepubertal mice," Fertility and Sterility, vol. 95, no. 8, pp. 2534-2537.e1, 2011.

[74] Q. Chen, X. Sun, J. Chen et al., "Direct rosiglitazone action on steroidogenesis and proinflammatory factor production in human granulosa-lutein cells," Reproductive Biology and Endocrinology, vol. 7, article 147, 2009.

[75] C. Grommes, G. E. Landreth, and M. T. Heneka, "Antineoplastic effects of peroxisome proliferator-activated receptor $\gamma$ agonists," The Lancet Oncology, vol. 5, no. 7, pp. 419-429, 2004.

[76] P. Tontonoz, S. Singer, B. M. Forman et al., "Terminal differentiation of human liposarcoma cells induced by ligands for peroxisome proliferator-activated receptor $\gamma$ and the retinoid $\mathrm{X}$ receptor," Proceedings of the National Academy of Sciences of the United States of America, vol. 94, no. 1, pp. 237-241, 1997.

[77] E. Elstner, C. Müller, K. Koshizuka et al., "Ligands for peroxisome proliferator-activated receptor $\gamma$ and retinoic acid receptor inhibit growth and induce apoptosis of human breast cancer cells in vitro and in BNX mice," Proceedings of the National Academy of Sciences of the United States of America, vol. 95, no. 15, pp. 8806-8811, 1998.

[78] E. Mueller, P. Sarraf, P. Tontonoz et al., "Terminal differentiation of human breast cancer through PPAR $\gamma$," Molecular Cell, vol. 1, no. 3, pp. 465-470, 1998.

[79] T. Kubota, K. Koshizuka, E. A. Williamson et al., "Ligand for peroxisome proliferator-activated receptor gamma (Troglitazone) has potent antitumor effect against human prostate cancer both in vitro and in vivo," Cancer Research, vol. 58, no. 15, pp. 3344-3352, 1998.

[80] J. A. Brockman, R. A. Gupta, and R. N. Dubois, "Activation of PPAR $\gamma$ leads to inhibition of anchorage-independent growth of human colorectal cancer cells," Gastroenterology, vol. 115, no. 5, pp. 1049-1055, 1998.

[81] P. Sarraf, E. Mueller, D. Jones et al., "Differentiation and reversal of malignant changes in colon cancer through PPAR $\gamma$," Nature Medicine, vol. 4, no. 9, pp. 1046-1052, 1998.

[82] T.-H. Chang and E. Szabo, "Induction of differentiation and apoptosis by ligands of peroxisome proliferator-activated receptor $\gamma$ in non-small cell lung cancer," Cancer Research, vol. 60, no. 4, pp. 1129-1138, 2000.

[83] W. Motomura, T. Okumura, N. Takahashi, T. Obara, and Y. Kohgo, "Activation of peroxisome proliferator-activated receptor gamma by troglitazone inhibits cell growth through the increase of p27KiP1 in human. Pancreatic carcinoma cells," Cancer Research, vol. 60, no. 19, pp. 5558-5564, 2000.

[84] Y.-F. Guan, Y.-H. Zhang, R. M. Breyer, L. Davis, and M. D. Breyer, "Expression of peroxisome proferator-activated receptor $\gamma(\operatorname{PPAR} \gamma)$ in human transitional bladder cancer and its role in inducing cell death," Neoplasia, vol. 1, no. 4, pp.330-339, 1999.

[85] H. Sato, S. Ishihara, K. Kawashima et al., "Expression of peroxisome proliferator-activated receptor (PPAR) $\gamma$ in gastric cancer and inhibitory effects of PPAR $\gamma$ agonists," British Journal of Cancer, vol. 83, no. 10, pp. 1394-1400, 2000.

[86] M. Terrasi, V. Bazan, S. Caruso et al., "Effects of PPAR $\gamma$ agonists on the expression of leptin and vascular endothelial growth factor in breast cancer cells," Journal of Cellular Physiology, vol. 228, no. 6, pp. 1368-1374, 2013.

[87] A. Cimini, E. Benedetti, R. Galzio, B. D’Angelo, and M. P. Cer, "PPARs in human neuroepithelial tumors: PPAR ligands as anticancer therapies for the most common human neuroepithelial tumors," PPAR Research, vol. 2010, Article ID 427401, 9 pages, 2010.

[88] A. Peri, I. Cellai, S. Benvenuti, P. Luciani, S. Baglioni, and M. Serio, "PPAR $\gamma$ in neuroblastoma," PPAR Research, vol. 2008, Article ID 917815, 7 pages, 2008.

[89] A. O. Isaac, I. Kawikova, A. L. M. Bothwell, C. K. Daniels, and J. C. K. Lai, "Manganese treatment modulates the expression of peroxisome proliferator-activated receptors in astrocytoma and neuroblastoma cells," Neurochemical Research, vol. 31, no. 11, pp. 1305-1316, 2006.

[90] A. Bonfigli, O. Zarivi, S. Colafarina et al., "Human glioblastoma ADF cells express tyrosinase, L-tyrosine hydroxylase and melanosomes and are sensitive to L-tyrosine and phenylthiourea," Journal of Cellular Physiology, vol. 207, no. 3, pp. 675$682,2006$.

[91] G. C. Burdge, H. Rodway, J. A. Kohler, and K. A. Lillycrop, "Effect of fatty acid supplementation on growth and differentiation of human IMR-32 neuroblastoma cells in vitro," Journal of Cellular Biochemistry, vol. 80, no. 2, pp. 266-273, 2000.

[92] S. Falone, M. R. Grossi, B. Cinque et al., "Fifty hertz extremely low-frequency electromagnetic field causes changes in redox and differentiative status in neuroblastoma cells," International Journal of Biochemistry and Cell Biology, vol. 39, no. 11, pp. 20932106, 2007.

[93] S. Moreno, S. Farioli-Vecchioli, and M. P. Cerù, "Immunolocalization of peroxisome proliferator-activated receptors and retinoid $\mathrm{x}$ receptors in the adult rat CNS," Neuroscience, vol. 123, no. 1, pp. 131-145, 2004.

[94] K. Wada, A. Nakajima, K. Katayama et al., "Peroxisome proliferator-activated receptor $\gamma$-mediated regulation of neural stem cell proliferation and differentiation," The Journal of Biological Chemistry, vol. 281, no. 18, pp. 12673-12681, 2006.

[95] K. M. Jung, K. S. Park, J. H. Oh et al., "Activation of p38 mitogen-activated protein kinase and activator protein-1 during the promotion of neurite extension of PC-12 cells by 15-deoxy812,14-prostaglandin J2," Molecular Pharmacology, vol. 63, no. 3, pp. 607-616, 2003.

[96] S. Han, R. K. Wada, and N. Sidell, "Differentiation of human neuroblastoma by phenylacetate is mediated by peroxisome proliferator-activated receptor gamma," Journal of Controlled Release, vol. 61, no. 10, pp. 3998-4002, 2001.

[97] T. Satoh, K. Furuta, M. Suzuki, and Y. Watanabe, "Prostaglandin $\mathrm{J}_{2}$ and its metabolites promote neurite outgrowth induced by nerve growth factor in PC12 cells," Biochemical and Biophysical Research Communications, vol. 258, no. 1, pp. 50-53, 1999.

[98] K.-D. Kwon, M. J. Choi, J.-M. Park et al., "Silencing histone deacetylase 2 using small hairpin RNA induces regression of fibrotic plaque in a rat model of Peyronie's disease," BJU International, vol. 114, no. 6, pp. 926-936, 2014.

[99] K. S. Park, R. Da Lee, S.-K. Kang et al., "Neuronal differentiation of embryonic midbrain cells by upregulation of peroxisome proliferator-activated receptor-gamma via the JNK-dependent pathway," Experimental Cell Research, vol. 297, no. 2, pp. 424433, 2004.

[100] A. Qaseem, L. L. Humphrey, D. E. Sweet, M. Starkey, and P. Shekelle, "Oral pharmacologic treatment of type 2 diabetes mellitus: a clinical practice guideline from the american college of physicians," Annals of Internal Medicine, vol. 156, no. 3, pp. 218 231, 2012

[101] D. M. Nathan, J. B. Buse, M. B. Davidson et al., "Medical management of hyperglycemia in type 2 diabetes: a consensus 
algorithm for the initiation and adjustment of therapy," Diabetes Care, vol. 32, no. 1, pp. 193-203, 2009.

[102] R. Würth, S. Thellung, A. Bajetto, M. Mazzanti, T. Florio, and F. Barbieri, "Drug-repositioning opportunities for cancer therapy: novel molecular targets for known compounds," Drug Discovery Today, vol. 21, no. 1, pp. 190-199, 2016.

[103] K. Kisfalvi, G. Eibl, J. Sinnett-Smith, and E. Rozengurt, "Metformin disrupts crosstalk between $G$ protein-coupled receptor and insulin receptor signaling systems and inhibits pancreatic cancer growth," Cancer Research, vol. 69, no. 16, pp. 6539-6545, 2009.

[104] M. B. Schneider, H. Matsuzaki, J. Haorah et al., "Prevention of pancreatic cancer induction in hamsters by metformin," Gastroenterology, vol. 120, no. 5, pp. 1263-1270, 2001.

[105] I. B. Sahra, K. Laurent, A. Loubat et al., "The antidiabetic drug metformin exerts an antitumoral effect in vitro and in vivo through a decrease of cyclin D1 level," Oncogene, vol. 27, no. 25, pp. 3576-3586, 2008.

[106] C. Algire, M. Zakikhani, M.-J. Blouin, J. H. Shuai, and M. Pollak, "Metformin attenuates the stimulatory effect of a high-energy diet on in vivo LLC1 carcinoma growth," Endocrine-Related Cancer, vol. 15, no. 3, pp. 833-839, 2008.

[107] L. Vitale-Cross, A. A. Molinolo, D. Martin et al., "Metformin prevents the development of oral squamous cell carcinomas from carcinogen-induced premalignant lesions," Cancer Prevention Research, vol. 5, no. 4, pp. 562-573, 2012.

[108] M. Buzzai, R. G. Jones, R. K. Amaravadi et al., "Systemic treatment with the antidiabetic drug metformin selectively impairs p53-deficient tumor cell growth," Cancer Research, vol. 67, no. 14, pp. 6745-6752, 2007.

[109] R. Würth, A. Pattarozzi, M. Gatti et al., "Metformin selectively affects human glioblastoma tumor-initiating cell viability: a role for metformin-induced inhibition of Akt," Cell Cycle, vol. 12, no. 1, pp. 145-156, 2013.

[110] F. Barbieri, S. Thellung, A. Ratto et al., "In vitro and in vivo antiproliferative activity of metformin on stem-like cells isolated from spontaneous canine mammary carcinomas: translational implications for human tumors," BMC Cancer, vol. 15, article 228, 2015.

[111] R. Rattan, R. Ali Fehmi, and A. Munkarah, "Metformin: an emerging new therapeutic option for targeting cancer stem cells and metastasis," Journal of Oncology, vol. 2012, Article ID 928127, 12 pages, 2012.

[112] G. Z. Rocha, M. M. Dias, E. R. Ropelle et al., "Metformin amplifies chemotherapy-induced AMPK activation and antitumoral growth," Clinical Cancer Research, vol. 17, no. 12, pp. 3993-4005, 2011.

[113] R. Rattan, S. Giri, L. C. Hartmann, and V. Shridhar, "Metformin attenuates ovarian cancer cell growth in an AMP-kinase dispensable manner," Journal of Cellular and Molecular Medicine, vol. 15, no. 1, pp. 166-178, 2011.

[114] F. Morgillo, F. C. Sasso, C. M. Della Corte et al., "Synergistic effects of metformin treatment in combination with gefitinib, a selective EGFR tyrosine kinase inhibitor, in LKB1 wild-type NSCLC cell lines," Clinical Cancer Research, vol. 19, no. 13, pp. 3508-3519, 2013.

[115] E. Karnevi, K. Said, R. Andersson, and A. H. Rosendahl, "Metformin-mediated growth inhibition involves suppression of the IGF-I receptor signalling pathway in human pancreatic cancer cells," BMC Cancer, vol. 13, article no. 235, 2013.

[116] M. Gritti, R. Würth, M. Angelini et al., "Metformin repositioning as antitumoral agent: selective antiproliferative effects in human glioblastoma stem cells, via inhibition of CLIC1mediated ion current," Oncotarget, vol. 5, no. 22, pp. 1125211268, 2014.

[117] W. S. Cheang, X. Y. Tian, W. T. Wong et al., "Metformin protects endothelial function in diet-induced obese mice by inhibition of endoplasmic reticulum stress through $5^{\prime}$ adenosine monophosphate-activated protein kinase-peroxisome proliferator-activated receptor $\delta$ pathway," Arteriosclerosis, Thrombosis, and Vascular Biology, vol. 34, no. 4, pp. 830-836, 2014.

[118] V. Ljubicic and B. J. Jasmin, "Metformin increases peroxisome proliferator-activated receptor $\gamma$ Co-activator- $1 \alpha$ and utrophin a expression in dystrophic skeletal muscle," Muscle \& Nerve, vol. 52, no. 1, pp. 139-142, 2015.

[119] E. Joly, R. Roduit, M.-L. Peyot et al., "Glucose represses PPAR $\alpha$ gene expression via AMP-activated protein kinase but not via p38 mitogen-activated protein kinase in the pancreatic $\beta$-cell," Journal of Diabetes, vol. 1, no. 4, pp. 263-272, 2009.

[120] C. Sedlinsky, M. S. Molinuevo, A. M. Cortizo et al., "Metformin prevents anti-osteogenic in vivo and ex vivo effects of rosiglitazone in rats," European Journal of Pharmacology, vol. 668, no. 3, pp. 477-485, 2011.

[121] M. S. Sozio, C. Lu, Y. Zeng, S. Liangpunsakul, and D. W. Crabb, "Activated AMPK inhibits PPAR- $\alpha$ and PPAR- $\gamma$ transcriptional activity in hepatoma cells," American Journal of PhysiologyGastrointestinal and Liver Physiology, vol. 301, no. 4, pp. G739G747, 2011.

[122] A. Maida, B. J. Lamont, X. Cao, and D. J. Drucker, "Metformin regulates the incretin receptor axis via a pathway dependent on peroxisome proliferator-activated receptor- $\alpha$ in mice," Diabetologia, vol. 54, no. 2, pp. 339-349, 2011.

[123] M. Castelnuovo, S. Massone, R. Tasso et al., "An Alu-like RNA promotes cell differentiation and reduces malignancy of human neuroblastoma cells," The FASEB Journal, vol. 24, no. 10, pp. 4033-4046, 2010.

[124] S. Massone, E. Ciarlo, S. Vella et al., "NDM29, a RNA polymerase III-dependent non coding RNA, promotes amyloidogenic processing of APP and amyloid $\beta$ secretion," Biochimica et Biophysica Acta (BBA)_Molecular Cell Research, vol. 1823, no. 7, pp. 1170-1177, 2012.

[125] A. Mescola, S. Vella, M. Scotto et al., "Probing cytoskeleton organisation of neuroblastoma cells with single-cell force spectroscopy," Journal of Molecular Recognition, vol. 25, no. 5, pp. 270-277, 2012.

[126] P. Gavazzo, S. Vella, C. Marchetti, M. Nizzari, R. Cancedda, and A. Pagano, "Acquisition of neuron-like electrophysiological properties in neuroblastoma cells by controlled expression of NDM29 ncRNA," Journal of Neurochemistry, vol. 119, no. 5, pp. 989-1001, 2011.

[127] S. Påhlman, A.-I. Ruusala, L. Abrahamsson, M. E. K. Mattsson, and T. Esscher, "Retinoic acid-induced differentiation of cultured human neuroblastoma cells: a comparison with phorbolester-induced differentiation," Cell Differentiation, vol. 14, no. 2, pp. 135-144, 1984.

[128] S. Vella, I. Penna, L. Longo et al., "Perhexiline maleate enhances antitumor efficacy of cisplatin in neuroblastoma by inducing over-expression of NDM29 ncRNA," Scientific Reports, vol. 5, Article ID 18144, 2015. 


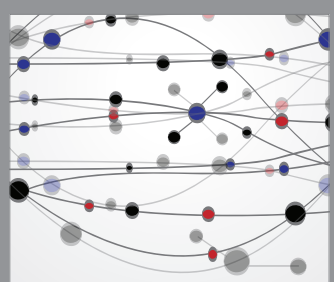

The Scientific World Journal
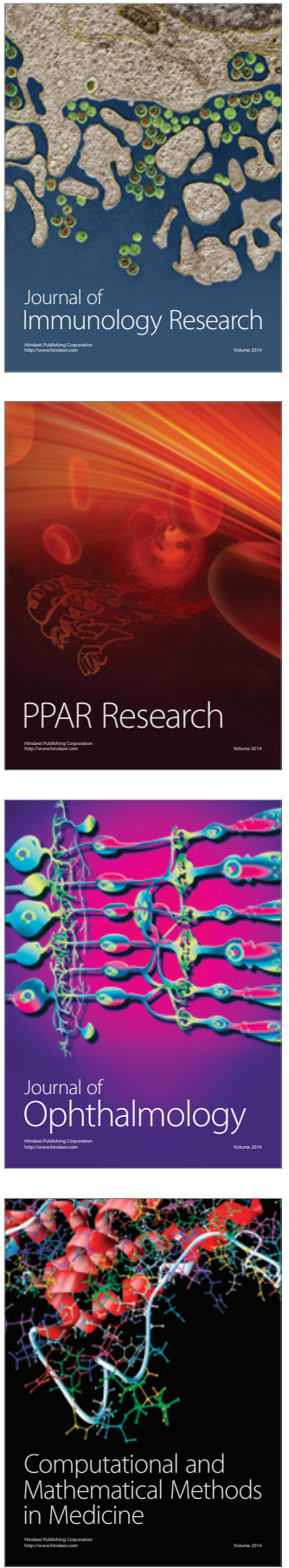

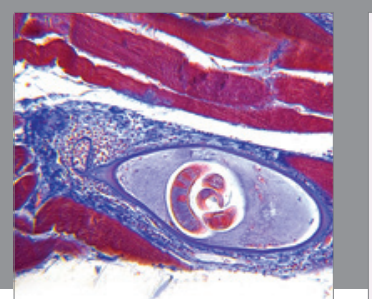

Gastroenterology Research and Practice

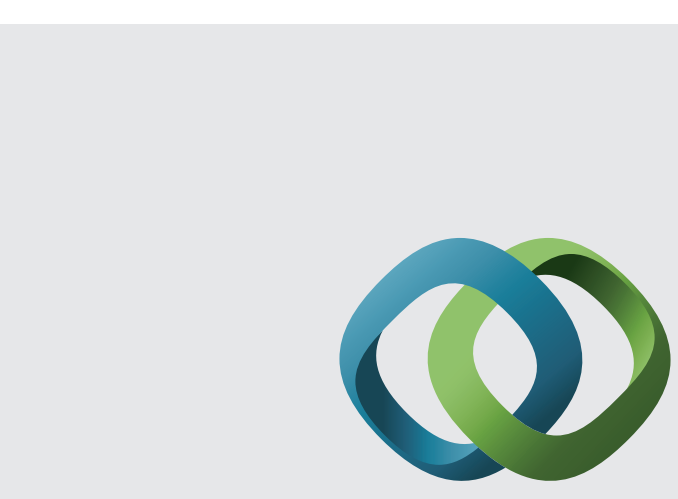

\section{Hindawi}

Submit your manuscripts at

http://www.hindawi.com
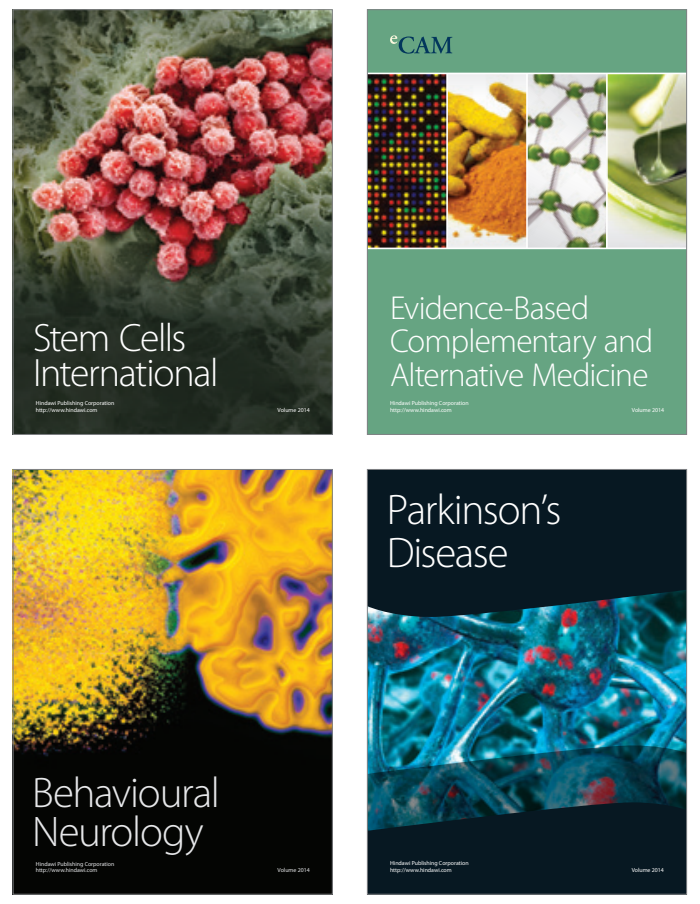
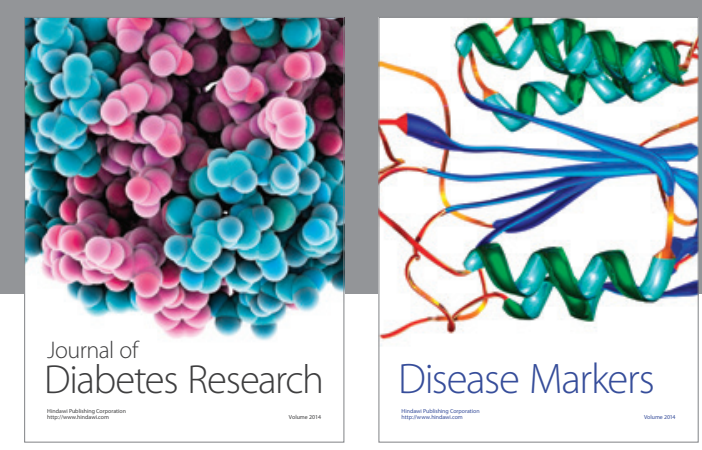

Disease Markers
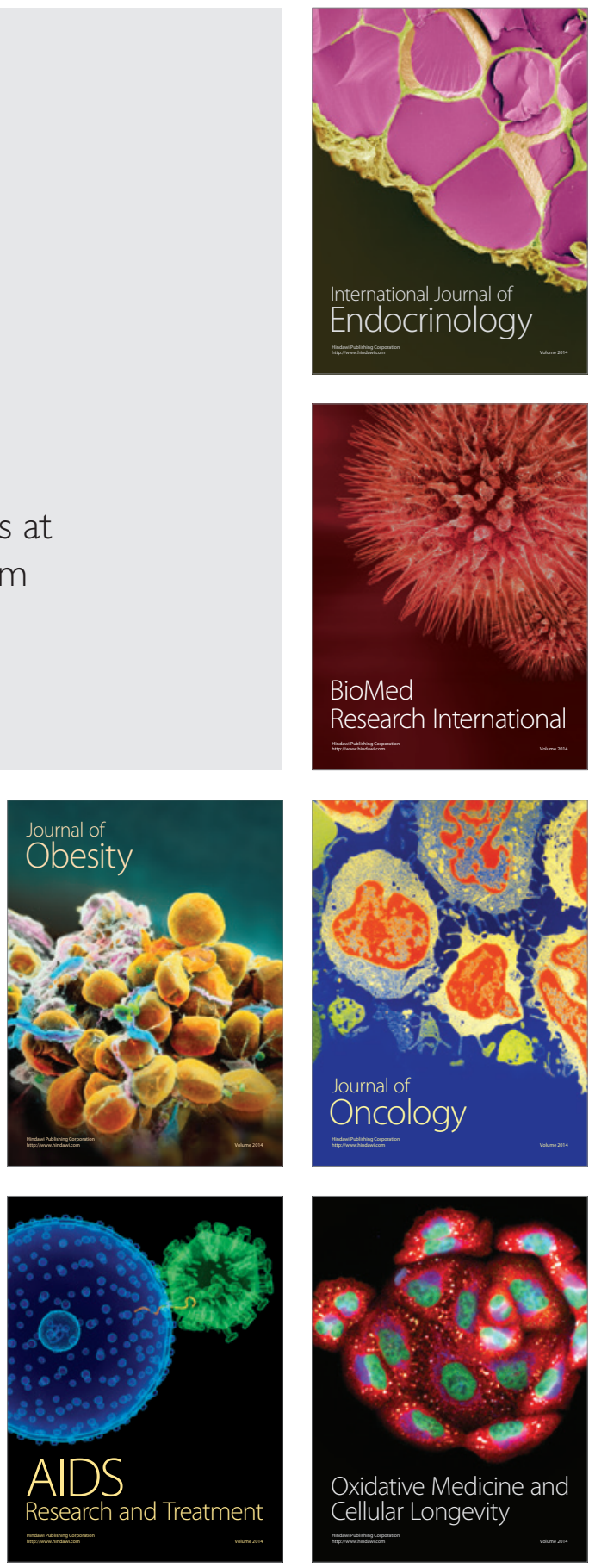